Article

\title{
Insurance Instruments in Estimating the Cost Energy Assets with Renewable Energy Sources
}

\author{
Ryszard Pukala ${ }^{1, *(D)}$, Nadezda Kirillova ${ }^{2}$ iD and Alexey Dorozhkin ${ }^{2}$ \\ 1 Bronislaw Markiewicz State University of Technology and Economics, 37-500 Jaroslaw, Poland \\ 2 Financial University under the Government of the Russian Federation, 125993 Moscow, Russia; \\ nvk_66@mail.ru (N.K.); adorozhkin@fa.ru (A.D.) \\ * Correspondence: ryszard.pukala@interia.pl
}

Citation: Pukala, R.; Kirillova, N.; Dorozhkin, A. Insurance Instruments in Estimating the Cost Energy Assets with Renewable Energy Sources. Energies 2021, 14, 3672. https:// doi.org/10.3390/en14123672

Academic Editor: Ignacio Mauleón

Received: 19 April 2021

Accepted: 17 June 2021

Published: 20 June 2021

Publisher's Note: MDPI stays neutral with regard to jurisdictional claims in published maps and institutional affiliations.

Copyright: (c) 2021 by the authors. Licensee MDPI, Basel, Switzerland. This article is an open access article distributed under the terms and conditions of the Creative Commons Attribution (CC BY) license (https:// creativecommons.org/licenses/by/ $4.0 /)$.
Abstract: The construction and commissioning of renewable energy sources is one of the priority areas of energy programs aimed at achieving sustainable development goals. The creation and operation of such sources is associated with significant risks, the management of which is based on real insurance instruments. This article focuses on the formation of a model for assessing the use of insurance in renewable energy projects and presents the business process, stages, risk drivers, and calculation of the economic efficiency of the use of insurance mechanisms in renewable energy projects.

Keywords: renewable energy sources; insurance; estimating model

\section{Introduction}

Currently, unlimited access to a broadly understood energy is necessary not only for the needs of industrial production and the activities of government agencies, but also for the effective functioning of every person in everyday life. It is difficult to imagine not having access to electricity for work and recreation, gasoline for driving, and natural gas for heating homes and cooking. It seems impossible to not have access to your phone, computer, or the Internet. We are not surprised how much we depend on energy sources, not to mention how important they are for the vital interests of the state and as a living organism in the international space.

The importance of electricity to modern civilization cannot be overstated. Along with an increase in the number of people inhabiting our planet, as well as an increase in their standard of living, the demand for electricity continues to grow. Thus, energy is an integral part of the functioning of any economy in the world [1]. It is the driving force of an economy and allows one to influence many of the processes taking place in it, ranging from stimulating economic growth $[2,3]$ through influence on the level of consumption [4] to creating and developing innovations [5].

In the global economy and the socio-economic development of individual countries, both at the regional and the local level, the principle of sustainable development, seen as a compromise between the needs of the environment, economy, and society, is becoming increasingly important [6]. Such development is defined as a process of change in which the use of resources, directions of investment, directions of technological progress, and institutional change remain in harmony and support current and future opportunities to meet human needs and aspirations $[7,8]$.

From the point of view of irreversible climate change, the phenomenon of resource reduction, climate warming, and an increase in environmental pollution, alternative solutions are being sought in all spheres of socio-economic life. The concept of sustainable development is a response to the needs of an increasingly competitive economy and a demanding market. An important role in this process is played by energy security, a state in which all (or most) of the inhabitants and enterprises in a state have access to sufficient energy resources at affordable prices, which are, in the foreseeable future, free from the risk 
of serious supply disruptions [9]. Energy security in the scientific community is analyzed, among other things, in terms of legal decisions, environmental impact, safety of critical infrastructure, energy independence of countries, and the efficiency of energy sources use, its role in the economy, or the search for new energy technologies [10]. Changes in the energy sector are driven by the following three factors: advances in technology, consumer environmental awareness, and regulatory pressures. On the one hand, these are incentives for a low-emission economy and, on the other, they are restrictive environmental standards and the need to adapt installations to the best available technologies [11-13].

The development of renewable energy sources depends on the possibility of using the energy potential and the policy of a given country in the field of supporting the development of renewable energy installations. Highly developed countries, located in regions that promote the development of renewable energy sources, have been investing for many years in renewable energy sources, which, being environmentally friendly, significantly reduce the consumption of natural energy resources, i.e., crude oil, coal or gas. According to the UN Renewable Energy Policy Network report for the 21st century (REN 21), 27.7\% of the world's installed capacity comes from renewable sources. This is mainly driven by hydropower and wind power. This share corresponds to meeting $22.8 \%$ of the global energy demand [14].

For example, hydropower is a clean, renewable energy source that does not produce greenhouse gases. It is actively exploited, especially in the most developed countries. Hydroelectric power plants are an important source of energy obtained from renewable energy sources in the energy systems of many countries of the world. Their importance will grow as new facilities are built and their energy efficiency improves [15]. During the operation of hydroelectric power plants, the issue of the risks associated with their operation, and the adoption of measures aimed at reducing the effects in the event of their implementation, becomes of great important [16-18].

The seventh goal of the UN's Sustainable Development Goals is low-cost and clean energy. The development of the energy sector ensures the growth of all industries, while it is important to reduce greenhouse gas emissions $(60 \%$ of emissions are generated by the energy sector) [19]. In accordance with the documents of the Sustainable Development Goals initiatives, it is assumed that the replacement of road and air transport by rail, and the development of public transport, will improve the quality of the energy infrastructure.

The energy sector directly affects the quality of life and economic growth in countries. The production and use of energy satisfy the needs of people, but it also exerts strong negative pressures on the environment through the associated greenhouse gas emissions, environmental pollution, and generation of nuclear waste [20]. Chovancová and Vavrek 2020, in their work "(De)coupling Analysis with Focus on Energy Consumption in EU Countries and Its Spatial Evaluation", presented a cross-country comparison of separation trends to assess the impact of economic growth on energy consumption and greenhouse gas emissions. The production and use of energy satisfy human needs, but also generate many adverse environmental impacts, such as greenhouse gas emissions, air and water pollution, the generation of waste, and many other negative effects [21].

Energy issues have become even more important during the pandemic. The Sustainable Energy for All Initiative has identified three ways to respond to a COVID-19 emergency:

1. Prioritizing energy solutions in order to provide electricity to medical clinics and first aid services;

2. Providing communication to vulnerable consumers;

3. Increasing reliable, uninterrupted, and sufficient energy production to prepare for a sustainable economic recovery.

An important issue is the source of clean energy, which, along with hydro and bioenergy, include renewable energy sources. Russia supports the achievement of the Sustainable Development Goals, with electricity production reaching 1.198 billion kWh [19]. 
Energy development and the problems of renewable energy sources receive considerable attention from the scientists, government organizations, and ministries of Europe and Russia [22-32]. At the same time, one of the crucial issues of use is the assessment of the energy efficiency of projects [33-36].

This article is based on an analysis of the current situation in the development of an important issue in the Russian Federation: renewable energy sources and the need for insurance support for renewable energy source projects [37-39]. The aim of the paper is to present the results of using insurance in renewable energy source projects. The article begins with a definition of "renewable energy sources" and presents the model of insurance instruments in estimating the cost of projects for the construction and operation of energy assets with renewable energy sources. The results of implementing the model with different driver complexes present the economic effect of $1-3 \%$ from the inclusion insurance program in the renewable energy sources projects.

\section{Materials and Methods}

Resolutions of the government of the Russian Federation on renewable energy (solar, wind, and small hydroelectric power plants up to $25 \mathrm{~kW}$ ), biogas, biomass, and landfill gas waste are valid until 2035. The Russian RES support program is planned for a budget of RUB 400 billion [40]. The key task is to increase the values of the installed capacity utilization factor and reduce the level of costs per unit of generated electric energy, which will lead to a gradual reduction in the price of electric energy generated by renewable energy facilities.

Risk management means identifying potential events or situations, assessing their consequences and likelihood of occurrence, identifying and applying appropriate response methods, and monitoring risk. An important element is to determine the causes of the risk, as well as to predict its possible consequences and take measures aimed at limiting its consequences [41,42]. Identification of a risk threatening the operation of hydroelectric power plants is the basis for taking measures aimed at modeling it and making management decisions in the fight against it $[43,44]$. One way to reduce the impact of risk is through insurance.

Currently, insurance is not only an effective risk management tool in limiting the consequences of risk materialization and taking preventive measures, but also in managing the value of an enterprise. Consequently, it can be used as an optimal risk management method in the operation of hydroelectric power plants and other renewable energy sources (RES) $[45,46]$.

The construction and operation of energy assets with RES are associated with a high level of risk. To reduce the level of risk as early as at the initial stages of project implementation, it is necessary to use insurance tools, which are an effective way of managing the risks of RES projects (Figure 1).

The purpose of applying the model for insurance effect in RES projects is to assess the impact of insurance risks on the cost of a project and its various stages. The model evaluates the inherent risks before the implementation of insurance instruments and the residual risks after assessing the effect of insuring RES projects.

The conceptual framework of the insurance impact assessment model is applicable to most RES projects (Figure 2).

The composition of the assessment of the business value of a renewable energy project consists of the net present value (price of electricity, sensitivity to certain factors, and the volume of electricity sales), net working capital (stocks and large accounts payable and receivable), and the volume of investments (Figure 3).

The assessment of the effect of insurance in the model is carried out in a number of stages, as shown in Figure 4. 


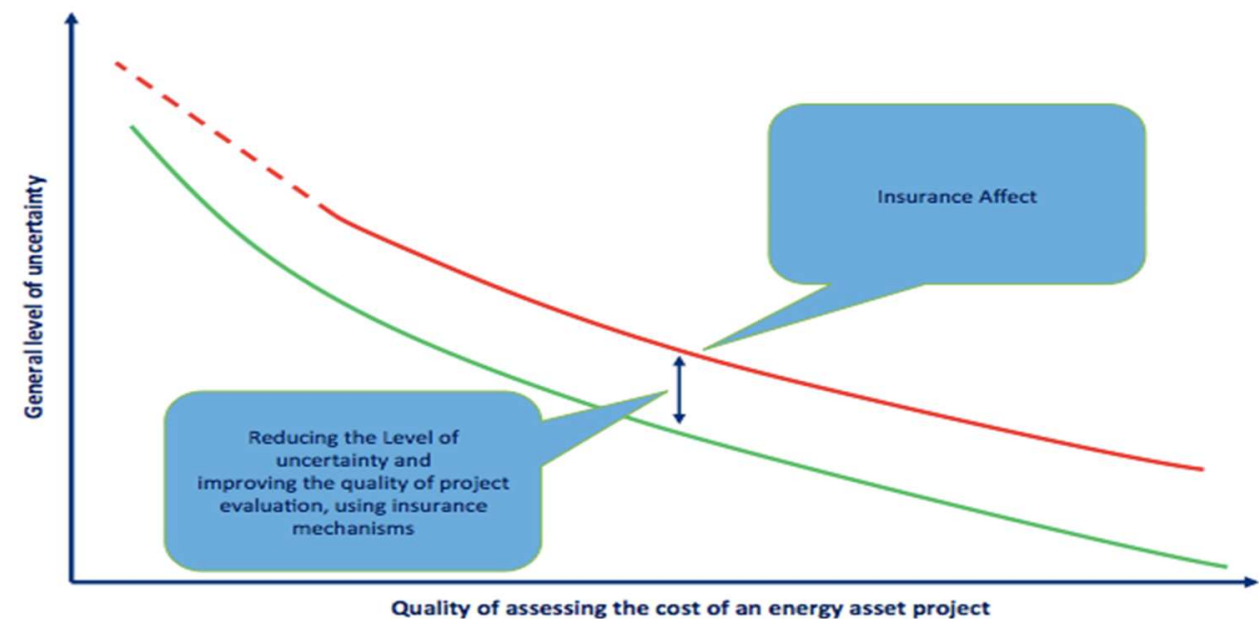

Figure 1. The insurance instruments implementation effect in the RES projects. Source: authors own design.

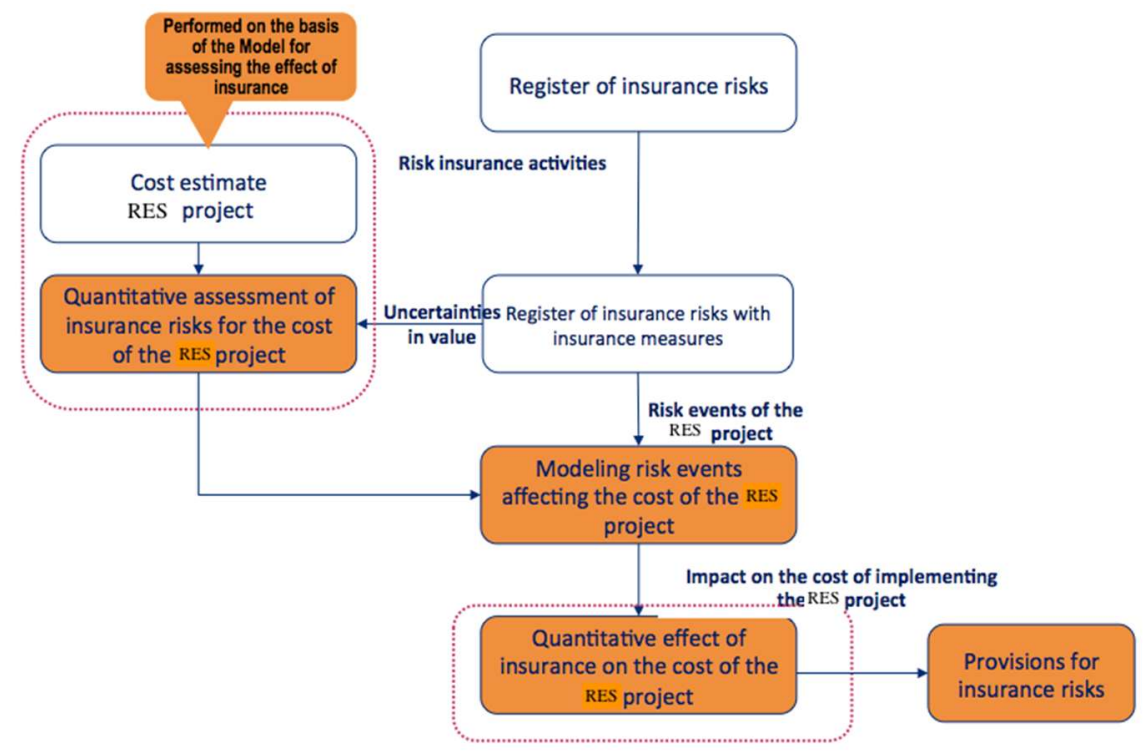

Figure 2. Conceptual scheme of the model for assessing the effect of insuring RES projects. Source: authors own design.

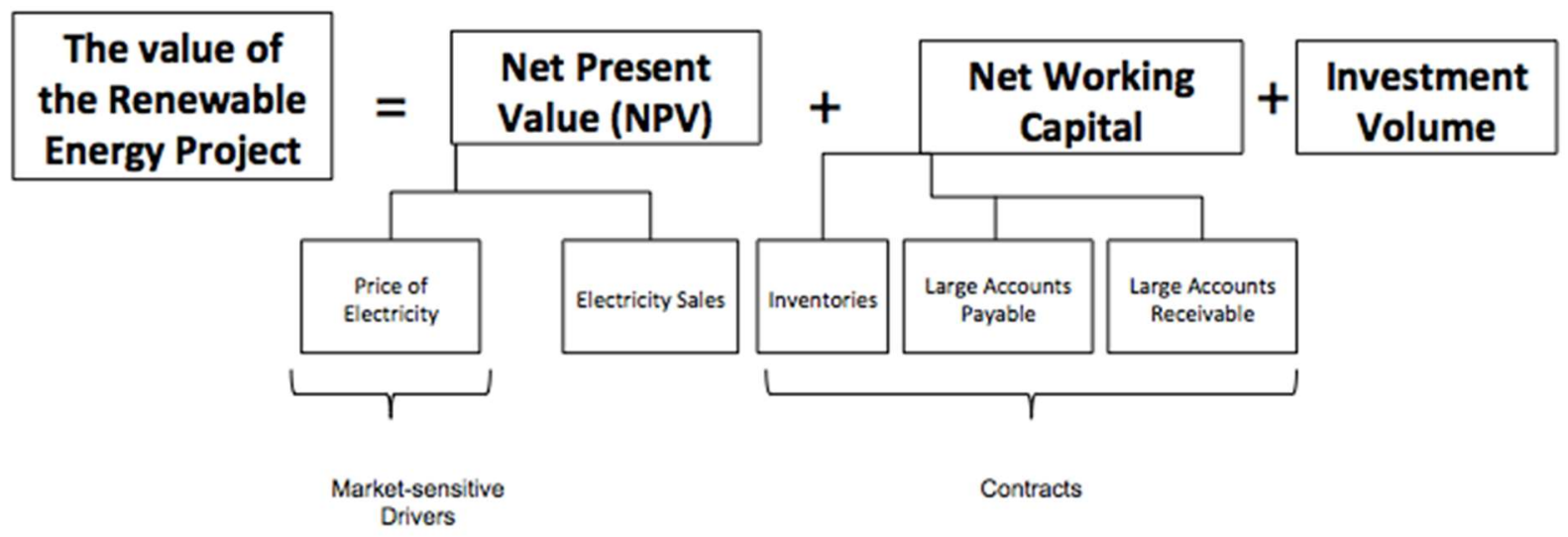

Figure 3. The value of the renewable energy sources project business. Source: authors own design. 


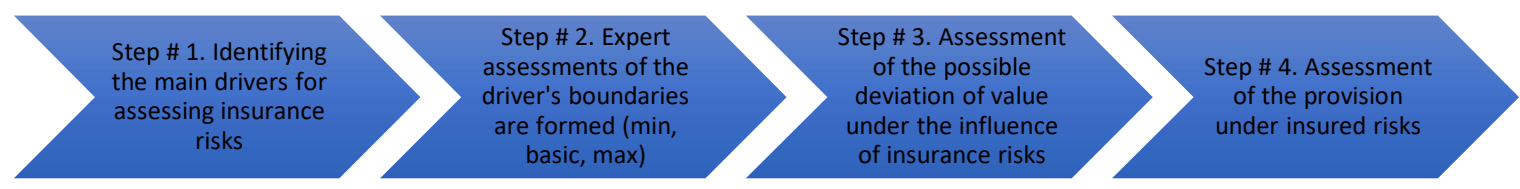

Figure 4. Business process of assessing insurance in projects. Designed by authors.

Stage 1. The main drivers for assessing insurance risks are identified.

The main risk drivers (macroparameters and scenario conditions) of a RES project include:

- Electricity generation volumes at the RES facility;

- Construction and installation costs;

- Maintenance costs;

- Electricity tariffs;

- Repair schedule;

- Cost of equipment;

- Insurance costs;

- Operating costs;

- Exchange rates.

Stage 2. Expert assessments of the driver's boundaries are formed (minimum, basic, and maximum).

Experts assess the facts of insurance risks to assess the magnitude of the possible deviation from the planned values of the cost of the RES project (Figure 5).

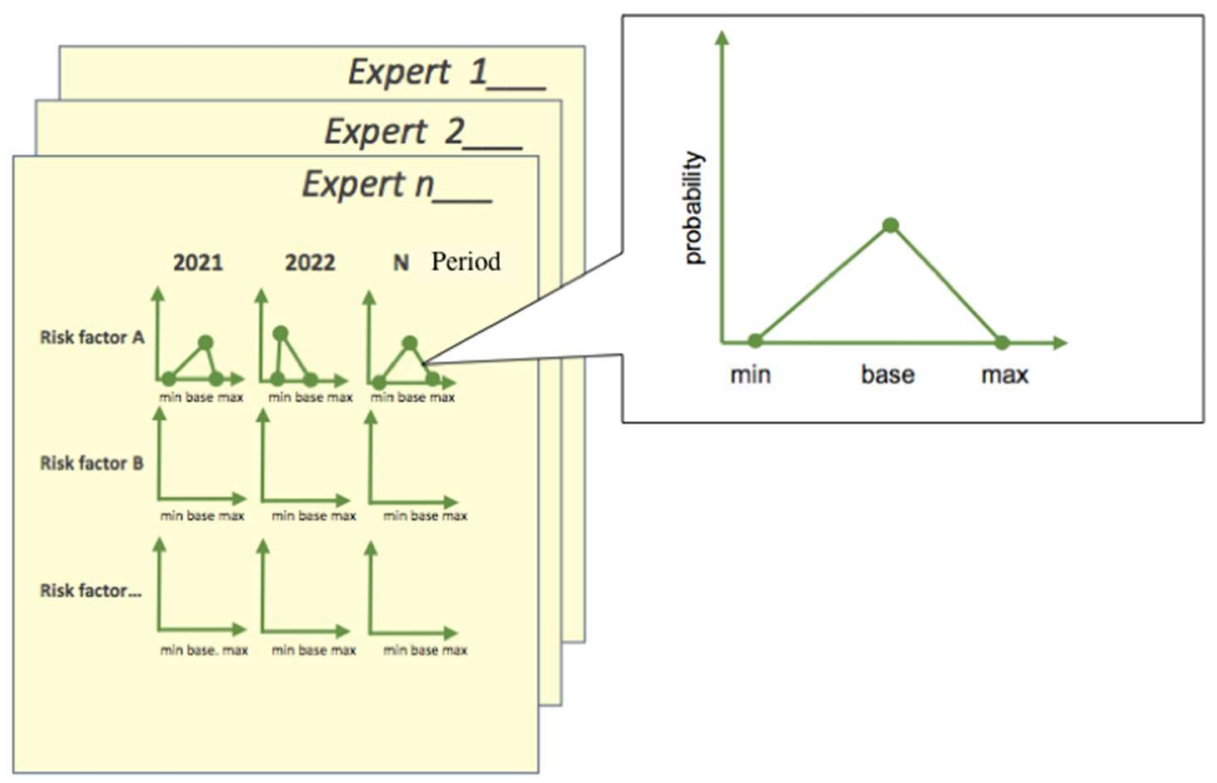

Figure 5. Assessment of drivers of the RES project model. Designed by authors.

To ensure the quality of an insurance risk assessment, it is necessary to determine the criteria for the selection of experts via their work experience, education, and participation in RES projects, etc. To obtain an integral assessment of insurance risk factors, expert assessments are averaged.

Stage 3. Possible deviation of the cost of projects under the influence of insurance risks is estimated.

At the third stage, an assessment of insurance risks is carried out, excluding insurance and accounting for the use of insurance instruments. For these conditions, a simulation of the project risks is carried out.

The final stage is the formation of reserves for insurance risks, which take the cost of the RES project into account (Figure 6). Based on the assessment of the effect of insurance, 
it is possible to form contingency reserves to compensate for uncertainties that could affect sustainable development.

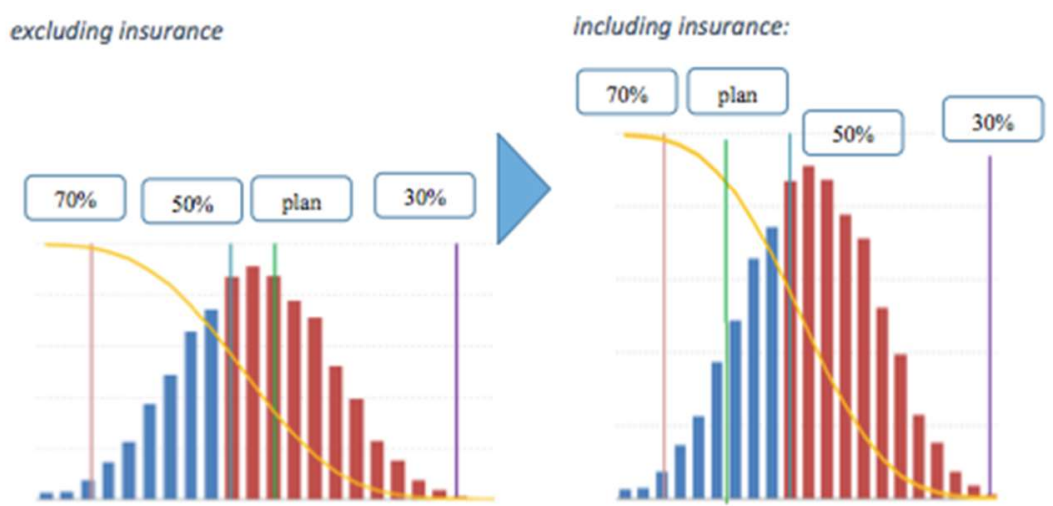

Figure 6. Formation of reserves for insurance: the probability of reaching the target (yellow line); red-positive prognosis, blue-unfavorable prognosis. Designed by authors.

The benefits of using simulation modeling include:

- Taking a large number of risk factors into account, including insurance risks of the RES project. It allows one to simulate the impact of insurance risks on any indicators of the RES project;

- Making it possible to include an assessment of uncertainty in project estimates and determine the integral impact of insurance risks on a RES project;

- Making it possible to justify the decision for the need to implement the RES project or to revise it from the point of view of the possibility of its insurance. It allows one to choose a risk management strategy, either accepting the risk or transferring risks to insurance, while decision-making.

An alternative calculation of the formation of the effect of insuring RES projects is the formation of regression models. The regression model includes the risk factors associated with ensuring the sustainable development of the RES project (Table 1).

This model was formed and tested by the risk management structures of corporate policyholders. Insurers are also offering new comprehensive products for insuring renewable energy projects. Insurers offer their new comprehensive insurance products designed specifically for renewable energy projects. For example, Allianz in Russia has offered a line of renewable energy insurance products with:

- Combined insurance "against all risks" through all stages of the project life cycle from design, transportation, and construction to operation. The policy covers all project participants and covers not only material damage, but also the related loss of profit, as well as civil liability;

- Unique for the Russian market, natural index insurance of lost revenue from lack of sun or wind;

- Consulting services for the assessment of the technical and investment model of the project, as well as its certification [47].

Insurers' ready-made solutions are convenient for start-up contracts or structures where risk management systems have not yet been formed. Studies of corporate industrial systems with developed risk management systems indicate the specificity of each insurance program, and the need to form it for different types of insurance with different deductibles and taking different value types as the insurance value. At the same time, the model considered can be used to assess the effectiveness of insurance in renewable energy projects. 
Table 1. Factors affecting sustainable development of the RES project.

\section{Sustainable Development Factor Area}

Approach to Assessing the Impact of Factors on Ensuring Sustainable Development

\section{RES project design}

1. The RES project is an atypical design solution

0 -there is

1 -no

2. Exceeding the planned construction period of the RES project over the world average

3. Availability of a prepared construction site for the RES project

4. RES production technology

Difference between the planned construction period of the RES project and the world average construction period for energy assets

0 -there is

$1-$ no

1 -worked out

$0-$ no
Number of projects managed by the operator

0 -there is

$1-$ no

0 - there is

1 -no

0 -there is

1 -no the RES project

During the construction of the RES project between the countries of the participants and the country of the customer, there was an aggravation of geopolitical relations

Economic conditions

10. State of GDP of the customer's country

$1-$ during the construction of the project in the customer's country there was a drop in GDP

0 -no

Accident at RES projects

11. Accidents at the RES project during construction in the customer's country

1 -an accident occurred during the construction of the RES project in the customer's country 0 -no

Factor area Approach to determining the significance of factors

12. Cumulative electric power of all RES facilities in the customer's country

Cumulative electric power of all previously constructed RES projects in the world.

Cumulative electric power of all previously built RES projects in the customer's country.

Source: authors. Mathematical proofs (the regression form) of results are in the Appendix A.

\section{Results}

The practical significance of preparing a model for assessing the effectiveness of insurance is to increase the efficiency of decision-making for the use of insurance tools as a mechanism for sustainable development for existing RES projects implemented by large energy companies in the Russian Federation.

Thus, calculating the economic effect of projects using the Monte Carlo method, we obtained the results using insurance, as shown in Table 2 and Figures 5 and 6. 
Table 2. Calculation of the cost of the RES project at risk before and after insurance, RUB billion.

\begin{tabular}{|c|c|c|c|}
\hline RES Project & $\begin{array}{c}\text { Calculation of the Cost } \\
\text { of the RES Project at Risk } \\
\text { before Insurance, RUB Billion }\end{array}$ & $\begin{array}{l}\text { Calculation of the Cost of the } \\
\text { RES Project at Risk after } \\
\text { Insurance, RUB Billion }\end{array}$ & $\begin{array}{c}\text { The Effect of a Decrease in the } \\
\text { Indicator of the Cost of a RES } \\
\text { Project at Risk Due to } \\
\text { Insurance, RUB Billion }\end{array}$ \\
\hline RES Project 1 & -1 & I.. & $\begin{array}{l}\text { RES project cost at risk (inherent } \\
\text { risk) }=2 \\
\text { RES project cost at risk (residual } \\
\text { risk) }=1 \\
\Delta \mathrm{Er}=1\end{array}$ \\
\hline RES Project 2 & IIn - & & $\begin{array}{l}\text { RES project cost at risk (inherent } \\
\text { risk) }=2 \\
\text { RES project cost at risk (residual } \\
\text { risk) }=1 \\
\Delta \mathrm{Er}=1\end{array}$ \\
\hline RES Project 3 & 118 & ${ }_{12} \frac{\ln \mid \operatorname{ll}}{\vdots}$ & $\begin{array}{r}\text { RES project cost at risk (inherent } \\
\text { risk) }=3 \\
\text { RES project cost at risk (residual } \\
\text { risk) }=2 \\
\Delta \mathrm{Er}=1\end{array}$ \\
\hline
\end{tabular}

Source: Authors' elaboration.

The proposed model, based on a comprehensive assessment of the cost indicators of a RES project under the influence of insurance risks, was tested on a real project of a renewable energy source: wind power projects in Russia at the development stage (Table 3).

The effectiveness of the use of insurance mechanisms in a project using a renewable energy source based on an assessment of the inherent, Table 4, and insurance, Table 5, risks was assessed using this model, the results are shown in the Table 3.

The effect of reducing risks due to the implementation of insurance instruments for almost all types of non-systemic risks reaches 100\% (Table 3). 
Table 3. Modeling the application of insurance instruments in estimating the cost of projects for the construction and operation of energy assets with renewable energy sources.

\section{Stages of Calculating the Effect}

of Insuring RES Projects

\section{Stage Description}

\section{Results}

The following risks were identified as affecting the RES project:

- Lack of approval of design estimates by the customer (or the developer);

- The need to develop additional documentation or amendments at the request of the licensing authority of the customer's country;

- Errors in the preparation of initial data for design (ID);

- Errors in the choice of the main technological equipment;

- Lack of technology or contractor work experience;

- Loss of design data due to loss of information during transmission and untimely accounting of information;

- Violation of the technological sequence of work;

- Lack of required technologies;

- Insufficient reliability of the applied work technology:

- IT risk (loss of information, complete or partial failure of IT infrastructure, and violation of license requirements);

- Damage to cargo (packaging) during loading or unloading of a vehicle;

- Damage to cargo (packaging) during transportation (the possibility of accidents, road accidents, etc.);

- Theft of goods during transportation and storage in intermediate warehouses;

Identification of risk drivers that - Mechanical damage to equipment as a result of unintentional actions of third parties when loading and transporting affect the cost of the project is carried out.
Identification of risk drivers for inclusion in the financial and economic model (FEM)

- Low quality of resources used for construction;

-Failures of engineering networks, including failure of external supporting systems (energy and water supply) bsidence of soil goods near or across the construction site

- Inadequate conditions for the performance of construction and installation work, including violation of labor protection standards, harm to the life and health of employees and third parties, including occupational diseases;

- Low quality construction and installation works (including installation and flushing);

- Delays in the manufacture and delivery of specialized or unique equipment (including delays in heavy equipment);

Deterioration of financial position as a result of consolidation and redistribution of financial flows;

- Jointly owned patents not recognized as intangible assets by one of the patent holders. Results of intellectual activity (RIA) is not used by the second patent holder directly in its own production activities;

- High volatility in the price of purchased products;

Low quality components;

- Change of equipment specification;

- Specific conditions for the acceptance of equipment by the customer;

- Violation of environmental safety regulations;

- Submission by the authors of RIA (their heirs) of requirements to the organization right-holder for payment of remuneration for the use of official RIA

- Contestation of a patent due to non-regulation of relations with the authors of the RIA;

- Lack of regulated terms for regulatory approvals. 
Table 3. Cont

\begin{tabular}{ll}
\hline $\begin{array}{l}\text { Stages of Calculating the Effect } \\
\text { of Insuring RES Projects }\end{array}$ & Stage Description \\
\hline & $\begin{array}{l}\text { Determination of FEM drivers in } \\
\text { the selection of risks to assess the } \\
\text { boundary values for modeling } \\
\text { inherent risks affecting the cost } \\
\text { of a RES project. }\end{array}$ \\
\end{tabular}

\section{Results}

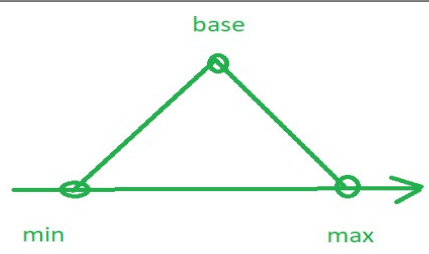

Table 4

The results of modeling the inherent risks of the RES project

Stage 3

Calculation of the cost of the RES project at risk before insurance,

RUB billion.

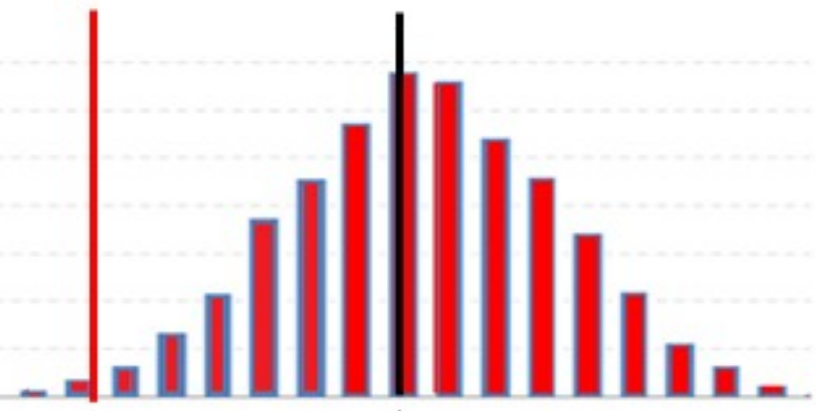

17 billjon rubles

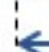

19 billion rubles

The delta between the percentiles P70\% and P90\% under the influence of inherent risks is RUB 2 billion.

Assessment of the effect of

reducing risks due to the

Stage 4

implementation of insurance

Table 5

instruments (effect of the

influence of risk, \%) 
Table 3. Cont

\section{Stages of Calculating the Effect}

of Insuring RES Projects

Stage Description

Calculation of the cost of the RES

Stage 5 billion rub.

\section{Results}

The results of modeling the inherent risks of the RES project, including the insurance program

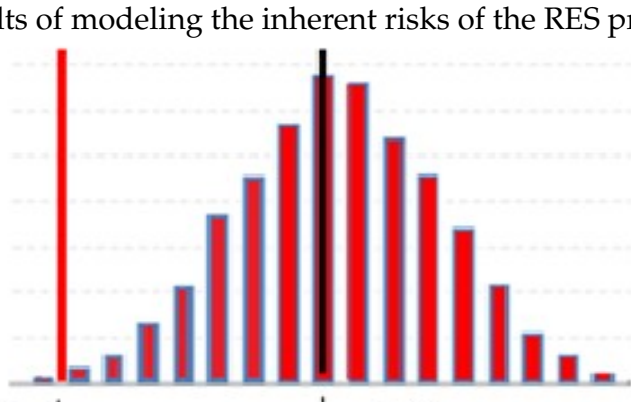

22.5

billion rub.

The delta between the P70\% and P90\% percentiles under the influence of the potential effect from the use of risk insurance instruments is RUB 1 billion.

RES project cost at risk (inherent risk) $=2$

RES project cost at risk (residual risk) $=1$

$\Delta \mathrm{Er}=1$

The model for assessing the effectiveness of insurance of the RES project allows us to determine the spread of the project cost values and to assess the effect of reducing the spread of the values by building, at the beginning of the distribution the cost of the project without the use of insurance instruments and why, accounting for the possible use of insurance instruments. 
Table 4. Calculation of the cost of the RES project at risk before insurance, RUB billion.

\begin{tabular}{|c|c|c|}
\hline Risks & FEM Drivers & Assessment, $\%$ \\
\hline $\begin{array}{l}\text { Lack of approval of design and estimate documentation by the } \\
\text { customer (or developer) }\end{array}$ & Cost of construction and installation works & $10-20$ \\
\hline $\begin{array}{l}\text { The need to develop additional documentation or amendments } \\
\text { at the request of the licensing authority of the customer's } \\
\text { country }\end{array}$ & Cost of construction and installation works & $5-10$ \\
\hline Errors in the preparation of initial data for design (ID and ITT) & Cost of construction and installation work & $5-10$ \\
\hline Errors in choosing the main technological equipment & Cost of equipment & $10-20$ \\
\hline The contractor has no technology or work experience & Cost of construction and installation works & $5-10$ \\
\hline $\begin{array}{l}\text { Loss of design data due to loss of information during shipment } \\
\text { and untimely registration of information }\end{array}$ & Cost of construction and installation works & $1-2$ \\
\hline Violation of the technological sequence of work execution & Cost of construction and installation work & $3-5$ \\
\hline Lack of required technologies & Cost of construction and installation works & $10-20$ \\
\hline Insufficient reliability of the applied work technology & Cost of construction and installation works & $3-5$ \\
\hline $\begin{array}{l}\text { IT risk (loss of information, complete or partial failure of IT } \\
\text { infrastructure, and violation of licensing requirements) }\end{array}$ & Cost of construction and installation work & $3-5$ \\
\hline $\begin{array}{c}\text { Damage to cargo (packaging) during loading or unloading of a } \\
\text { vehicle }\end{array}$ & Transportation costs & $2-5$ \\
\hline $\begin{array}{l}\text { Damage to the cargo (packaging) during transportation (the } \\
\text { possibility of accidents, road accidents, etc.) }\end{array}$ & Transportation costs & $2-5$ \\
\hline $\begin{array}{l}\text { Theft of goods during transportation and storage in } \\
\text { intermediate warehouses }\end{array}$ & Transportation costs & $2-5$ \\
\hline Low quality of resources used for construction & Cost of construction and installation works & $5-10$ \\
\hline $\begin{array}{l}\text { Failures of engineering networks, including failure of external } \\
\text { supporting systems (power and water supply) }\end{array}$ & Cost of construction and installation works & $20-30$ \\
\hline Subsidence of soil & Cost of construction and installation works & $15-20$ \\
\hline $\begin{array}{l}\text { Mechanical damage to equipment as a result of unintentional } \\
\text { actions of third parties when loading and transporting goods } \\
\text { near or through the construction site }\end{array}$ & Cost of equipment & $5-10$ \\
\hline $\begin{array}{l}\text { Inadequate conditions for the performance of construction and } \\
\text { installation work, including violation of labor protection } \\
\text { standards, harm to the life and health of employees and third } \\
\text { parties, including occupational diseases }\end{array}$ & Cost of construction and installation work & $10-15$ \\
\hline $\begin{array}{l}\text { Low quality of construction and installation works (including } \\
\text { installation and flushing) }\end{array}$ & Cost of construction and installation works & $15-25$ \\
\hline $\begin{array}{l}\text { Delays in the manufacture and delivery of specialized or } \\
\text { unique equipment (including delays in heavy equipment) }\end{array}$ & Construction and installation costs & $5-10$ \\
\hline $\begin{array}{c}\text { Deterioration of financial position as a result of pooling and } \\
\text { redistribution of financial flows }\end{array}$ & Debt negotiation cost & $10-15$ \\
\hline $\begin{array}{l}\text { Jointly owned patents are not recognized as intangible assets by } \\
\text { one of the patent holders. RID is not used by the second patent } \\
\text { holder directly in its own production activities }\end{array}$ & Operating costs & $5-10$ \\
\hline High price volatility for purchased products & Operating costs & $10-20$ \\
\hline Low quality components & Cost of equipment & $5-10$ \\
\hline Change of equipment specification & Cost of equipment & $5-10$ \\
\hline $\begin{array}{c}\text { Specific conditions for the acceptance of equipment by the } \\
\text { customer }\end{array}$ & Cost of equipment & $15-20$ \\
\hline
\end{tabular}


Table 5. Calculation of the cost of the RES project at risk after insurance, RUB billion.

\begin{tabular}{|c|c|}
\hline Risks & $\begin{array}{l}\text { The Reducing Risks Effect Due to the Insurance Instruments } \\
\text { Implementation (Effect of the Influence of Risk, until \%) }\end{array}$ \\
\hline - Errors in the preparation of initial data for design (ID and ITT) & 50 \\
\hline - Violation of the technological sequence of work & 70 \\
\hline $\begin{array}{l}\text { - IT risk (loss of information, complete or partial failure of IT } \\
\text { infrastructure, and violation of license requirements) }\end{array}$ & 100 \\
\hline $\begin{array}{l}\text { - Damage to cargo (packaging) during loading or unloading of a } \\
\text { vehicle }\end{array}$ & 100 \\
\hline $\begin{array}{l}\text { - Damage to the cargo (packaging) during transportation (the } \\
\text { possibility of accidents, road accidents, etc.) }\end{array}$ & 100 \\
\hline $\begin{array}{l}\text { - Theft of goods during transportation and storage in } \\
\text { intermediate warehouses }\end{array}$ & 100 \\
\hline - Low quality of resources used for construction & 50 \\
\hline $\begin{array}{l}\text { - Failures of engineering networks, including failure of external } \\
\text { supporting systems (energy and water supply }\end{array}$ & 100 \\
\hline - Subsidence of soil & 100 \\
\hline $\begin{array}{l}\text { - Mechanical damage to equipment as a result of unintentional } \\
\text { actions of third parties when loading and transporting goods } \\
\text { near or across the construction site }\end{array}$ & 100 \\
\hline $\begin{array}{l}\text { - Inadequate conditions for the performance of construction and } \\
\text { installation work, including violation of labor protection } \\
\text { standards, harm to the life and health of employees and third } \\
\text { parties, including occupational diseases }\end{array}$ & 70 \\
\hline $\begin{array}{l}\text { - Low quality construction and installation works (including } \\
\text { installation and flushing) }\end{array}$ & 70 \\
\hline $\begin{array}{l}\text { - Delays in the manufacture and delivery of specialized or } \\
\text { unique equipment (including delays in heavy equipment) }\end{array}$ & 50 \\
\hline $\begin{array}{l}\text { - Deterioration of financial position as a result of consolidation } \\
\text { and redistribution of financial flows }\end{array}$ & 90 \\
\hline - Low quality components & 50 \\
\hline - Violation of environmental safety regulations & 100 \\
\hline
\end{tabular}

\section{Discussion}

In the absence of sufficient statistical data on the implementation of RES risks, in both domestic and international companies, equal ranges of indicators were used in the scales for assessing the level of risks for the boundary values of quantitative indicators, which ensured standardization and smoothing of the ranges for the selected quantitative indicators. The practice of establishing uniform boundaries of ranges has also been confirmed by the practice of international and domestic companies, which, when assessing the risks of their investment projects, use scales with the same boundaries to assess risks [48,49]. At the same time, the boundary values of qualitative indicators for assessing risks were taken on the basis of the benchmark of domestic companies, for which a textual description of the boundaries for assessing risks that do not have a sufficient amount of statistical information is presented.

The proposed architecture of the model, based on the integrated assessment of the cost indicators of the RES project under the influence of insurance risks, allowed us to measure the effectiveness of insurance based on the assessment of the inherent and residual insurance risks of the RES project already at the planning stage. The developed model for 
assessing the effect of the use of insurance tools allows you to make timely decisions on the use of insurance tools and justify the most effective method of insurance, in terms of the impact on the cost of the RES project.

Currently, energy and raw materials play an important role in the formulation of geopolitical concepts and strategies in many countries. Energy resources are strategically important for the energy security of the state and competitiveness of the economy. They transform political relations, define opportunities for economic development, and their scarcity can become a source of conflict.

Energy crises of the past have taught many leaders not to restrict the development of the energy sector, because if electricity, oil, or natural gas were not available, economic development would be significantly slowed or completely stopped [50-53].

Currently, energy security cannot be limited to acquisition of energy resources, but this extremely complex problem, related not only to energy production itself, but also to broadly understood policies, economic growth, and social stabilization [54], must be solved on the basis of the latest, innovative and effective solutions.

This paper examined the modeling of the application of insurance instruments in estimating the cost of projects for the construction and operation of energy assets with renewable energy sources. The construction of the model is based on the basic theoretical approaches to assessing the risks of industrial projects and the practical experience of the authors in the energy sector and insurance.

The model for assessing the effectiveness of insuring an RES project allowed us to determine the spread of the values of the project cost and to assess the effect of reducing the spread of the values by building at the beginning of the distribution of the cost without the use of insurance instruments and taking the possible use of insurance instruments into account.

In checking the results of the use of insurance for projects of renewable energy sources, the basic complexes of risk drivers were empirically selected. This does not, however, exclude further verification and refinement of the model, including accounting for the types of energy sources. Further development requires a study of the optimal complexes of insurance programs for such projects.

Nevertheless, already in this basic form, the model will be useful and possible for practical use in risk management of renewable energy projects using insurance mechanisms.

\section{Conclusions}

As of 4 May 2021, the Russian Ministry of Energy is responsible for the implementation of the President's Address to the Federal Assembly of the Russian Federation of 21 April 2021.

Among others, this includes:

- Ensuring the implementation of innovative projects of state importance aimed at the development and implementation of new approaches in the field of nuclear power generation, hydrogen energy, renewable energy sources, as well as energy storage;

- Ensuring the implementation of innovative projects of state importance aimed at creating a national system for high-precision monitoring and the utilization of climatically active gases, including to ensure legal regulation in the field of regulating emissions of such gases and environmental (low-carbon) transformation of economic sectors;

- Ensuring the introduction of amendments to the legislation of the Russian Federation providing for the implementation, by the owners of industrial and other infrastructure facilities whose activities harm to the environment, of the timely elimination of such harm at all stages of the life cycle of these facilities, including financial support for the fulfillment of this obligation.

The use of insurance support mechanisms for renewable energy projects is economically justified [55]; in addition, it involves additional financial and labor resources in such projects. Further areas of research will be devoted to the development of business 
processes and mechanisms for the interaction of the insurance and energy markets in the implementation of renewable energy projects.

Author Contributions: Conceptualization, data curation, writing-original draft preparation, supervision, methodology, software, validation, formal analysis, investigation, resources, R.P., N.K., and A.D. All authors have read and agreed to the published version of the manuscript.

Funding: This research received no external funding.

Data Availability Statement: The study did not report any data.

Conflicts of Interest: The authors declare no conflict of interest.

\section{Appendix A}

Mathematical proofs of results.

Regression form:

$$
\begin{aligned}
& \Delta S_{p}=\beta_{1, p}^{S}\left(x_{1}\right)+\beta_{5, p}^{S}\left(x_{5}\right)+\beta_{6, p}^{S}\left(x_{6}\right)+\beta_{7, p}^{S}\left(x_{7}\right)+\beta_{8, p}^{S}\left(x_{8}\right)+\beta_{9, p}^{S}\left(x_{9}\right)+\beta_{10, p}^{S}\left(x_{10}\right)+\beta_{11, p}^{S}\left(x_{11}\right)+\beta_{12, p}^{S}\left(x_{12}\right) \\
& \Delta C_{p}=\beta_{2, p}^{C}\left(x_{2}\right)+\beta_{4, p}^{C}\left(x_{4}\right)+\beta_{8, p}^{C}\left(x_{8}\right)+\beta_{9, p}^{C}\left(x_{9}\right)+\beta_{10, p}^{C}\left(x_{10}\right)+\beta_{11, p}^{C}\left(x_{11}\right) \\
& F=\beta_{1}^{F}\left(x_{1}\right)+\beta_{2}^{F}\left(x_{2}\right)+\beta_{3}^{F}\left(x_{3}\right)+\beta_{6}^{F}\left(x_{6}\right)+\beta_{12}^{F}\left(x_{12}\right) \\
& \beta_{j, p}^{i}\left(x_{j}\right)=\left\{\begin{array}{c}
\gamma_{j, p}^{i} x_{j} \text { if } j \in\{1 \ldots 7,12 \ldots 14,16 \ldots 18\} \\
\gamma_{j, p}^{i} \cdot \max \left\{0,\left(x_{95 \%, j}-x_{j}\right)\right\} \text { if } j \in\{8 \ldots 11,15\}
\end{array}\right.
\end{aligned}
$$

where:

$x_{j}$ - the value of the risk factor $j$;

$x_{95 \%, j}-90 \%$ percentile of values of risk factor $j$ in the considered sample;

$\Delta S_{p}$-the premium for the insurance risks of the RES project period from the start of construction to the power start-up of the project, in calendar months;

$\Delta C_{p}$-an allowance for operational risks of the cost of a renewable energy project per kilowatt of electrical power;

F-Probability of termination of the construction of the RES project at the construction stage as a result of the implementation of operational risks, in percent;

$x_{1}$-Factor "The RES project is an atypical design solution";

$x_{2}$-Factor "Exceeding the planned construction period of the RES project over the world average";

$x_{3}$-Factor "Availability of a prepared construction site for the RES project";

$x_{4}$-Factor "Technology for obtaining RES";

$x_{5}$-Factor "Operator's experience in managing the RES project";

$x_{6}$-Factor "Experience of a supplier of equipment for the RES project";

$x_{7}$-Factor "The experience of the general contractor in the construction of the RES project";

$x_{8}$-Factor "Experience of the customer's country regulator in the RES project";

$x_{9}$-Factor "Geopolitical tension between the countries participating in the RES project and the customer country";

$x_{10}$-Factor "State of GDP of the customer's country";

$x_{11}$-Factor "Accidents at the RES project during construction in the customer's country";

$x_{12}$-Factor "Cumulative electrical power of all RES facilities in the customer's country"; $\beta_{j, p}^{i}\left(x_{j}\right)$-weight function for factor $x_{j}$ in equation $i$ for percentile $p$;

$\gamma_{j, p}^{i}$-the weighting factor for factor $x_{j}$ in equation $i$ for percentile $p$.

When adding the projected markups to the basic planned cost of the RES project without taking the measures for insurance risks into account, the values of the risk values of the cost of the RES project can be obtained: 
$C_{p}=d^{C}+\Delta C_{p}$

$C_{p}$ is the cost of the RES project, accounting for the impact of insurance risks for the percentile $p$;

$d^{C}$ is the base cost of construction of the RES project;

$\Delta C_{p}$ is the reserve for insurance risks of the cost of the RES project percentile $p$.

\section{References}

1. Stiglitz, J. Growth with Exhaustible Natural Resources: Efficient and Optimal Growth Paths. Rev. Econ. Stud. 1974, 41, 123. [CrossRef]

2. Stern, D.I. Modeling International Trends in Energy Efficiency and Carbon Emissions; Environmental Economics Research Hub Research Report 1054; The Australian National University: Canberra, Australia, 2010.

3. Soimakallio, S.; Saikku, L. CO $\mathrm{CO}_{2}$ emissions attributed to annual average electricity consumption in OECD (the Organisation for Economic Co-operation and Development) countries. Energy 2012, 38, 13-20. [CrossRef]

4. Stern, D.I.; Cleveland, C.J. Energy and Economic Growth. In Working Papers in Economics, No. 0410; Department of Economics, Rensselaer Polytechnic Institute, The Australian National University: Canberra, Australia, 2004.

5. Cleveland, C.J.; Kaufmann, R.K.; I Stern, D. Aggregation and the role of energy in the economy. Ecol. Econ. 2000, 32, 301-317. [CrossRef]

6. Costantini, V.; Martini, C. The causality between energy consumption and economic growth: A multi-sectoral analysis using non-stationary cointegrated panel data. Energy Econ. 2010, 32, 591-603. [CrossRef]

7. Bretschger, L. Economics of technological change and the natural environment: How effective are innovations as a remedy for resource scarcity? Ecol. Econ. 2005, 54, 148-163. [CrossRef]

8. Ackerman, F.; Daniel, J. (Mis) Understanding Climate Policy: The Role of Economic Modelling; WWF: Cambridge, UK, 2014. Available online: https:/ / www.foe.co.uk/sites/default/ files/downloads/synapsemisunderstanding-climate-policy-low-res46332.pdf (accessed on 19 June 2021).

9. ICF International. Economic Analysis of US Decarbonization Pathways: Summary and Findings; ICF International: Faifax, VA, USA, 2015.

10. European Commission. A Framework Strategy for a Resilient Energy Union with a Forward-Looking Climate Change Policy. 2015. Available online: https:/ /www.eea.europa.eu/policy-documents/com-2015-80-final (accessed on 17 November 2020).

11. Barton, B.; Redgwell, C.; Ronne, A.; Zillman, D.N. Managing Risk in a Dynamic Legal and Regulatory Environment, Energy Security; Oxford University Press: New York, NY, USA, 2004; p. 5.

12. Redgwell, C. International Legal Responses to the Challenges of a Lower-Carbon Future: Climate Change, Carbon Capture and Storage, and Biofuels. In Beyond the Carbon Economy. Energy Law in Transition; Zillman, D.N., Redgwell, C., Omorogbe, Y.O., Barrera-Hernandez, L.K., Eds.; Oxford University Press: New York, NY, USA, 2008; pp. 85-108.

13. Tosun, J.; Biesenbenderm, S.; Schulze, K. Energy Policy Making in the EU Building the Agenda; Springer: London, UK, 2015.

14. Morata, F.; Solorio, I. European Energy Policy: An Environmental Approach; Edward Elgar: Cheltenham, UK, 2012.

15. Hildingsson, R.; Kronsell, A.; Khan, J. The green state and industrial decarbonisation. Environ. Politics 2019, 28, 909-928. [CrossRef]

16. Renewable Energy Policy Network for the 21st Century (REN 21). Available online: https://sustainabledevelopment.un. org/partnership/?p=1619\#: \{\}:text=REN21\%20is\%20a\%20global\%20policy,in\%20developing\%20and\%20industrialised\%20 economies (accessed on 19 June 2021).

17. Harrison, G.; Whittington, H.W.; Wallace, R. Sensitivity of hydropower performance to climate change. Int. J. Power Energy Syst. 2006, 26, 1-21. [CrossRef]

18. Saedi, A.; Thambirajah, J.; Pariatamby, A. A HIRARC model for safety and risk evaluation at a hydroelectric power generation plant. Saf. Sci. 2014, 70, 308-315. [CrossRef]

19. Cook, B.R. Environmental Hazards: Assessing Risk and Reducing Disaster. Disasters 2010, 34, 589-591. [CrossRef]

20. Kucukali, S. Risk assessment of river-type hydropower plants using fuzzy logic approach. Energy Policy 2011, 39, 6683-6688. [CrossRef]

21. United Nations. Sustainable Development Goals. Clean Energy. Why Is It Important. Available online: https://www.un.org/ru/ development/devagenda/pdf/Russian_Why_it_matters_Goal_7_Clean_Energy.pdf (accessed on 16 April 2021).

22. Chovancová, J.; Vavrek, R. Decoupling Analysis of Energy Consumption and Economic Growth of V4 Countries. Probl. Ekorozw. Probl. Sustain. Dev. 2019, 14, 159-165.

23. Chovancová, J.; Vavrek, R. (De)coupling Analysis with Focus on Energy Consumption in EU Countries and Its Spatial Evaluation. Pol. J. Environ. Stud. 2020, 29, 2091-2100. [CrossRef]

24. Isoaho, K.; Moilanen, F; Toikka, A. A Big Data View of the European Energy Union: Shifting from 'a Floating Signifier' to an Active Driver of Decarbonisation? Politics Gov. 2019, 7, 28-44. [CrossRef]

25. European Commission. Overview of the European Energy System. 2021. Available online: https://www.eea.europa.eu/dataand-maps/indicators/overview-of-the-european-energy-system-3 (accessed on 16 April 2021).

26. Eurostat. Energy Productivity. 2021. Available online: https://ec.europa.eu/eurostat/web/products-datasets/-/t2020_rd310 (accessed on 16 April 2021). 
27. Eurostat. Renewable Energy Statistics. Eurostat 2021. Available online: https:/ / ec.europa.eu/eurostat/statistics-explained/index. php/Renewable_energy_statistics\#: \{\}:text=In\%202019\%2C\%20renewable\%20energy\%20represented,the \%202020\%20target $\%$ 20of $\% 2020 \% 20 \% 25 . \&$ text $=$ The $\% 20$ share $\% 20$ of $\% 20$ energy $\% 20$ from, 27\%20reached $\% 208.9 \% 20 \% 25 \% 20 \mathrm{in} \% 202019$ (accessed on 16 April 2021).

28. Pellerin-Carlin, T. The European Energy Union. Research Handbook on EU Energy Law and Policy; Edward Elgar Publishing: Cheltenham, UK, 2017.

29. Meeus, L.; Purchala, K.; Belmans, R. Development of the internal electricity market in Europe. Electron. J. 2005, 18, 25-35. [CrossRef]

30. Rozentale, L.; Blumberga, D. Methods for Evaluate Electricity Policy for Climate Perspective. Environ. Clim. Technol. 2019, 23, 131-147. [CrossRef]

31. Vavrek, R. Evaluation of the Impact of Selected Weighting Methods on the Results of the TOPSIS Technique. Int. J. Inf. Technol. Decis. Mak. 2019, 18, 1821-1843. [CrossRef]

32. Olczak, M.; Piebalgs, A. What to Expect from the 2020 Gas Package. Politics Gov. 2019, 7, 165-169. [CrossRef]

33. Pukala, R. Use of neural networks in risk assessment and optimization of insurance cover in innovative enterprises. Eng. Manag. Prod. Serv. 2016, 8, 43-56. [CrossRef]

34. Ministry of Economic Development of the Russian Federation. Available online: https://economy.gov.ru/ (accessed on 16 April 2021).

35. Vavrek, R.; Chovancová, J. Energy Performance of the European Union Countries in Terms of Reaching the European Energy Union Objectives. Energies 2020, 13, 5317. [CrossRef]

36. Mussapirov, K.; Jalkibaeyev, J.; Kurenkeyeva, G.; Kadirbergenova, A.; Petrova, M.; Zhakypbek, L. Business scaling through outsourcing and networking: Selected case studies. Entrep. Sustain. Issues 2019, 7, 1480-1495. [CrossRef]

37. Kirillova, N.V.; Dorozhkin, A.V. The Perspectives of Implementing Digitization Technologies for the Insurance Risks Assessment. Available online: http:/ / apps.webofknowledge.com/full_record.do?product=WOS\&search_mode=GeneralSearch\&qid= 32\&SID=C4p6Zm8sBGrVfy4ViBn\&page=1\&doc=1\&cacheurlFromRightClick=no (accessed on 19 June 2021).

38. Pukala, R.; Petrova, M. Application of the AHP Method to Select an Optimal Source of Financing Innovation in the Mining Sector. In Proceedings of the E3S Web of Conferences; EDP Sciences, Kemerovo, Russia, 14-16 October 2019; Volume 105, p. 04034.

39. Bank of the Russian Federation. Insurance. Available online: https:/ /www.cbr.ru/insurance/reporting_stat/ (accessed on 16 April 2021).

40. Tsyganov, A.; Kirillova, N. Regional Aspect of the Russian Insurance Market. Econ. Reg. 2018, 14, 1270-1281. [CrossRef]

41. Tsyganov, A.; Baskakov, V.; Yazykov, A.; Sheparnev, N.; Yanenko, E.; Grysenkova, Y. The impact of the bonus-malus system on the insurance ratemaking in the system of compulsory insurance of the responsibility of transport owners in Russia. Appl. Econom. 2019, 56, 123-141.

42. Ministry of Energy of Russian Federation. Available online: https://minenergo.gov.ru/activity/statistic (accessed on 16 April 2021).

43. Vassoney, E.; Mochet, A.M.; Comoglio, C. Use of multicriteria analysis (MCA) for sustainable hydropower planning and management. J. Environ. Manag. 2017, 196, 48-55. [CrossRef]

44. Anderson, D.R. The Critical Importance of Sustainability Risk Management. Risk Manag. 2006, 53, 66.

45. Zhang, S.; Sun, B.; Yan, L.; Wang, C. Risk identification on hydropower project using the IAHP and extension of TOPSIS methods under interval-valued fuzzy environment. Nat. Hazards 2013, 65, 359-373. [CrossRef]

46. Xu, X.H.; Cao, J. Risk evaluation for complex ecological environment of large-scale hydropower engineering. Syst. Eng. Theory Pract. 2012, 32, 2237-2246.

47. Guerritore, W.B. Insurance as a Risk Management Instrument for Energy Infrastructure Security and Resilience; Nova Science Publishers, Inc.: Hauppauge, NY, USA, 2013. Available online: https:/ / www.energy.gov/sites / prod/files/2013/03/f0/03282013_Final_ Insurance_EnergyInfrastructure.pdf (accessed on 19 June 2021).

48. JSC IC Allianz. Available online: https:/ /www.allianz.ru/ru_RU/shared/press-center/press-releases/allianz-v-rossii-zapustillineyku-produktov-po-strakhovaniyu-vozobnovlyaemykh-istochnikov-energii.html (accessed on 8 June 2021).

49. Kirillova, N.V. Risk management systems in insurance companies. World New Econ. 2016, 10, 116-123. (In Russia)

50. Tsyganov, A.; Kirillova, N.; Kurganov, V. Insurance Mechanisms of Financial Support in the Field of Energy Conservation Activities. Financ. J. 2016, 2, 100-110.

51. Stern, D.I.; Kander, A. The role of energy in the Industrial Revolution and modern economic growth. Energy J. 2012, 33. [CrossRef]

52. Chevalier, J.-M.; Ouédraogo, N.S. Energy Poverty and Economic Development. In The New Energy Crisis: Climate, Economics and Geopolitics; Palgrave Macmillan: London, UK, 2009; pp. 115-144.

53. Zhernov, E.; Nekhoda, E.; Petrova, M. Economic Transformation Impact on the Modernization of a Mineral Resource Industry Cluster. In Proceedings of the E3S Web of Conferences, Kemerovo, Russia, 14-16 October 2020; Volume 174, p. 04003.

54. Anger, A.; Barker, T. Finance and the Macroeconomics of Environmental Policies: The Effects of the Financial System and Financial Crises on Global Growth and the Environment; Palgrave Macmillan: Basingstoke, UK, 2015; pp. 153-193.

55. Ayres, R.U.; Warr, B. The Economic Growth Engine; Edward Elgar: Cheltenham, UK; Northamptom, MA, USA, 2009. 